\title{
Identifikasi Sanitasi Rumah Sehat dengan Metode Multifactor Evaluation Process
}

\author{
Dasril Aldo $^{1}$, Julius Santony ${ }^{2}$, Gunadi Widi Nurcahyo ${ }^{3}$ \\ 1,2,3 Jurusan Magister Komputer, Fakultas Ilmu Komputer, Universitas Putra Indoensia YPTK Padang \\ Jl. Raya Lubuk Begalung, Kota Padang, 25221 \\ Email: dasrilaldo1994@gmail.com, juliussantony@yahoo.co.id, gunadiwidi@yahoo.co.id
}

\begin{abstract}
ABSTRAK
Penelitian ini bertujuan untuk memudahkan pihak Pusat Kesehatan Masyarakat dalam mengidentifikasi sanitasi rumah sehat. Sebagai pendukung dalam penelitian ini, akan menggunakan metode Multifactor Evaluation Process untuk melakukan analisis terhadap 20 data sanitasi yang didapatkan dari Pusat Kesehatan Masyarakat Seberang Padang dengan kriteria penilaian berupa Komponen Rumah, Sarana Sanitasi dan Prilaku Penghuni. Tahapan dari metode ini yaitu menetapkan bobot evaluasi masing-masing kriteria, menentukan nilai evaluasi faktor dan menghitung nilai total evaluasi sebagai nilai akhir dalam pengambilan keputusan. Dari pengujian terhadap 20 data sanitasi mendapatkan hasil berupa rumah tidak sehat 70\% dan rumah sehat 30\% dengan memperoleh $95 \%$ terhadap hasil yang didapatkan oleh pihak Pusat Kesehatan Masyarakat Seberang Padang. Dengan kecocokan tersebut maka metode ini cocok digunakan dalam identifikasi sanitasi rumah sehat.
\end{abstract}

Kata Kunci: Identifikasi, Multifactor Evaluation Process, Sanitasi Rumah Sehat, Sistem Pendukung Keputusan

\begin{abstract}
This study aims to facilitate the Public Health Center in identifying healthy home sanitation. As a supporter in this study, the Multifactor Evaluation Process will be used to analyze 20 sanitation data obtained from the Public Health Center Seberang Padang with assessment criteria in the form of Home Components, Sanitation and Behavior Facilities for Residents. The stages of this method are determining the evaluation weight of each criterion, determining the value of factor evaluation and calculating the total value of evaluation as the final value in decision making. From the testing of 20 sanitation data, the results were in the form of unhealthy houses $70 \%$ and healthy houses $30 \%$ with a $95 \%$ match to the results obtained by the Public Health Center Seberang Padang. With this suitability, this method is suitable for use in identifying healthy home sanitation.
\end{abstract}

Keywords: Identification, Multifactor Evaluation Process, Healthy Home Sanitation, Decision Support Systems

Corresponding Dasril Aldo:

Program Studi Magister Komputer, Fakultas Ilmu Komputer,

Universitas Putra Indonesia YPTK Padang,

Email: dasrilaldo1994@gmail.com

\section{Pendahuluan}

Sanitasi merupakan prioritas dalam peningkatan pelayanan kesehatan masyarakat dengan cara melakukan pengawasan terhadap faktor-faktor dalam lingkungan fisik manusia yang dapat menimbulkan pengaruh yang merugikan terhadap perkembangan jasmani. Sanitasi dapat juga didefinisikan sebagai suatu usaha untuk menurunkan jumlah penyakit manusia sehingga derajat kesehatan yang optimal dapat dicapai. Tidak seluruh penduduk di Indonesia yang menikmati sanitasi, seperti masyarakat golongan yang tinggal di lingkungan padat, kumuh dan masyarakat kurang mampu. Salah satu faktor yang mempengaruhi sanitasi adalah pertumbuhan ekonomi yang bersamaan dengan kepadatan penduduk yang dapat mengakibatkan peningkatan limbah konsumen sehingga dapat menjadi ancaman kesehatan dan sanitasi, baik di daerah pedesaan maupun perkotaan [1]. Salah satu bentuk penilaian sanitasi yaitu sanitasi terhadap rumah.

Menurut World Health Organization (WHO), rumah adalah struktur fisik atau bangunan untuk tempat berlindung, di mana lingkungan berguna untuk kesehatan jasmani dan rohani serta keadaan sosialnya baik untuk kesehatan keluarga dan individu. Healthy home atau disebut juga sebagai rumah sehat merupakan rumah atau tempat tinggal yang sanggup memenuhi kebutuhan rohani dan jasmani secara layak sebagai perlindungan 
dari pengaruh alam luar maupun tempat tinggal. Pada rumah sehat harus memenuhi tiga komponen kesehatan di antaranya yaitu komponen rumah, sarana sanitasi, dan prilaku penghuni. Jika rumah dan lingkungan tersebut tidak memenuhi syarat kesehatan maka dapat menjadi resiko sumber dari penularan berbagai jenis penyakit [2]. Bentuk pencegahan awal penyakit tersebut terlebih dahulu dilakukan penilaian terhadap kondisi sanitasi rumah tersebut. dalam memudahkan penilaian dapat menggunakan Sistem Pendukung Keputusan (SPK).

SPK berkaitan dengan Sistem Informasi [3]. Pemanfaatan sistem informasi berbasis teknologi komputer akan mendorong sebuah institusi untuk memanfaatkan teknologi tersebut dalam segala bidang, salah satunya sistem pengolahan data yang sangat cepat dan akurat [4]. Penerapan SPK dapat diterapkan pada berbagai aspek. Konsep SPK sangat dibutuhkan dalam mendukung tahapan-tahapan dalam mengambil suatu keputusan, yang dimulai dari identifikasi masalah, pemilihan data, penentuan-penentuan pendekatan dan mengevaluasi pemilihan alternatif dalam proses pengambilan keputusan [5].

Penelitian menganai SPK oleh Mohamed dkk, (2016) dengan menggunakan metode Decision-Tree dan Case Base Reasoning (CBR) yang dapat memberikan keputusan mengenai kegiatan yang dilakukan dalam pelaksanaan ibadah haji berdasarkan pertanyaan yang diberikan oleh user [6]. Penelitian selanjutnya mengenai SPK oleh Khadke dkk, (2017) dengan menggunakan metode C4.5 Decision Tree Algorithm mampu menghasilkan prediksi kemungkinan hasil panen berdasarkan input dasar seperti ketersediaan air, suhu rata-rata, rata-rata ph tanah pertanian, daerah pertanian, jenis tanah dan durasi tanaman [7]. Penelitian lainnya mengenai SPK oleh Abdelghany dkk, (2018) dengan menggunakan metode Genetic Algorithms yang mampu mengatur lalu lintas dengan memprediksi skenario ketidakpastian melalui pembuatan skema manajemen lalu lintas yang akurat sehingga mampu mengurangi tingkat kemacetan [8]. Penelitian lainnya mengenai SPK oleh Polmetra, (2018) dengan menggunakan metode AHP menghasilkan keputusan berupa pemilihan pelatih bulu tangkis yang jujur, adil, dan transparan [9].

Metode yang digunakan dalam penelitian ini adalah Multifactor Evaluation Process (MFEP), di mana metode ini merupakan metode pendekatan kuantatif [10]. Terdapat penelitian terdahulu menggunakan metode MFEP oleh Widjaja dan Mujito, (2017) yang dapat diterapkan untuk pemilihan anggota Penyidik Polisi Investigasi Kriminal yang menghasilkan siapa saja anggota yang sesuai memenuhi kriteria penyidik [11]. Jurnal penelitian berikutnya oleh Maricar dkk, (2016) dengan metode Analytical Hierarchy Process (AHP) dan MFEP dapat memberikan rekomendasi karyawan yang diterima di perusahaan PT.XYZ [12]. Jurnal penelitian lainnya oleh Primadasa and Amalia, (2017) dengan Penerapan Metode MFEP untuk Pemilihan Tanaman Pangan di Kabupaten Musi Rawas yang menghasilkan rekomendasi jenis tanaman pangan yang cocok [13].
Selanjutnya jurnal penelitian lainnya oleh Turaina dan Efendy, (2016) mengenai metode MFEP untuk Sistem Penunjang Keputusan Penerimaan Calon Tenaga Honorer Di SMA N 1 Junjung Sirih Kab. Solok yang menghasilkan keputusan untuk membantu kepala Sekolah dalam menerima informasi penerimaan calon Tenaga Honorer dengan cepat dan tepat [14]. Berdasarkan penelitian terdahulu mengenai SPK dan metode MFEP, peneliti akan melakukan penelitian mengenai SPK untuk Identifikasi Sanitasi Rumah Sehat.

Biasanya petugas Pusat Kesehatan Masyarakat (PUSKESMAS) mendata langsung ke rumah masyarakat. Data didapatkan dari pengisian angket sanitasi dan harus melakukan proses pengolahan terhadap data tersebut terlebih dahulu secara manual, sehingga memakan banyak waktu dan terkadang terdapat kesalahan dalam pengelompokan rumah masyarakat dikarnakan kesalahan terhadap nilai hasil yang didapat. Pada penelitian ini, dengan menerapkan SPK dengan metode MFEP dapat mengatasi masalah sanitasi tersebut.

\section{Metode Penelitian}

Metode diperlukan guna untuk membantu penulisan dapat terarah sesuai dengan masalah yang diteliti. Metode tersebut harus berifat kritis, analisis yang berarti metode menunjukan adanya proses yang tepat dan benar untuk mendefenisikan masalah dan menentukan metode untuk pemecahan masalah tersebut. Metode tersebut juga harus bersifat logis, yang berarti metode yang digunakan untuk memberikan argumentasi ilmiah. Metode tersebut bersifat obyektif, artinya obyekfitas itu menghasilkan penyelidikan yang dapat dicontoh oleh peneliti lainnya dalam studi dan kondisi yang sama pula.Metode yang digunakan dalam penelitian ini yaitu MFEP, Dalam metode MFEP hal yang dilakukan pertama kali adalah menetapkan seluruh kriteria yang menjadi faktor penting dalam melakukan pertimbangan diberikan pembobotan (weighting) yang sesuai. Langkah yang sama juga dilakukan terhadap alternatif- alternatif yang akan dipilih, yang kemudian dapat dievaluasi berkaitan dengan faktor- faktor pertimbangan tersebut. MFEP banyak digunakan dengan alasan konsepnya sederhana dan mudah dipahami, komputusinya efesien, memiliki kemempuan untuk mengukur kinerja relatif dan alternatif - alternatif keputusan dalam bentuk matematis yang sederhana. Langkah-langkah dalam metode MFEP:

1. Perhitungan nilai bobot evaluasi faktor ditunjukkan dalam persamaan (1).

$$
\begin{aligned}
& E F=\frac{\sum x}{\sum x \max }(1) \\
& \text { Di mana: } \\
& E F: \text { Evaluasi Faktor } \\
& X: \text { Nilai subkriteria } \\
& X \text { max : Nilai } \mathrm{x} \text { max }
\end{aligned}
$$

2. Perhitungan nilai bobot evaluasi ditunjukkan dalam persamaan (2).

$$
W E=F W^{*} E(2)
$$


Di mana :

$W E$ : Nilai bobot evaluasi

$F W$ : Nilai bobot faktor

$E$ : Nilai evaluasi faktor

3. Perhitungan nilai total evaluasi ditunjuk dalam persamaan (3).

$$
\begin{aligned}
& \sum_{i=1}^{n} W E_{i}=W E_{1}+W E_{2}+W E_{n}(3) \\
& \text { Di mana: } \\
& \sum_{i=1}^{n}: \text { Total nilai bobot evaluasi } \\
& \text { WEi : Nilai bobot evaluasi ke } \mathrm{i}
\end{aligned}
$$

Urutan proses dari penelitian ini dapat dilihat pada Gambar 1. Di mana setiap bagian diuraikan setelah Gambar 1.

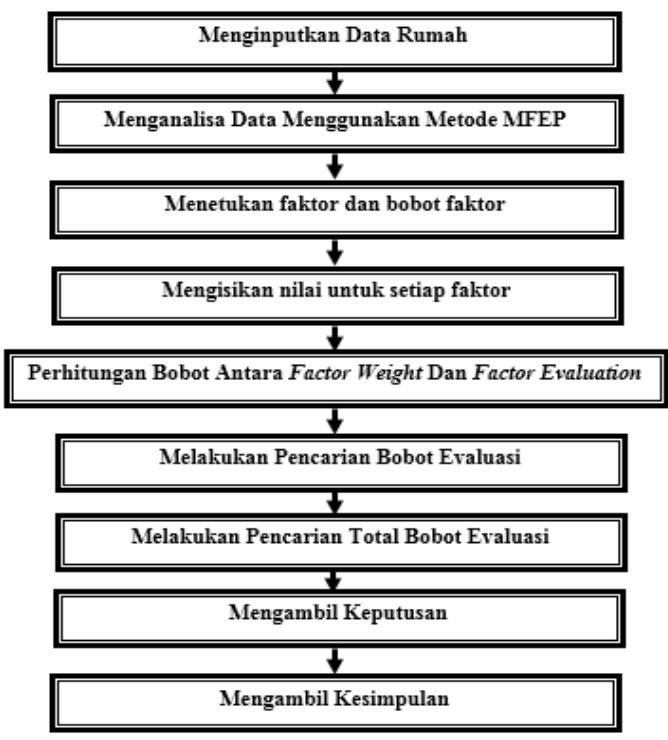

Gambar 1. Alur Metode Penelitian

a. Menginputkan data rumah

Merupakan proses memasukan data rumah yang nantinya akan diproses dengan menggunakan metode MFEP.

b. Menganalisa data menggunakan metode MFEP Merupakan proses menganalisa terhadap data yang telah diinputkan pada tahap sebelumnya.

c. Menetukan faktor dan bobot faktor

Merupakan proses untuk menentukan kriteriakriteria yang digunakan dalam metode MFEP brserta bobot untuk setiap kriteria.

d. Mengisikan nilai untuk setiap faktor

Merupakan proses memasukan nilai-nilai yang ada pada data rumah kedalam masing-masing kriteria atau faktor yang telah ditentukan.

$e$. Perhitungan bobot antara factor weight dan factor evaluation.

Merupakan proses mencari nilai evaluasi faktor dengan cara membagi nilai setiap bobot faktor dengan jumlah bobot keseluruhan.

f. Melakukan pencarian bobot evaluasi

Merupakan proses yang dilakukan setelah mendapatkan nilai evaluasi yaitu dengan menjumlahkan nilai setiap sub faktor kemudian embagi nilai tersebut dengan nilai maksimal faktor kemudian mengalikan dengan nilai evaluasi faktor.

g. Melakukan pencarian total bobot evaluasi

Setelah didapatkan nilai evalusi setiap sub faktor, maka dijumlahkan sehingga mendapatkan nilai akhir.

h. Mengambil keputusan

Setelah didapatkan nilai akhir, maka akan dilakukan pengambilan keputusan berdasarkan nilai yang didapatkan.

i. Mengambil kesimpulan

Kesimpulan yang diambil berupa hasil persentase identifikasi yang didapat berupa rumah sehat dan rumah tidak sehat serta apakah metode MFEP cocok atau tidak digunakan dalam penilaian sanitasi rumah sehat.

\section{Hasil dan Pembahasan}

Dalam penelitian ini menggunakan 20 data, Data ini berupa inputan kriteria yang sudah ditentukan oleh pihak PUSKESMAS, di mana kriteria tersebut adalah Kompnen Rumah, Sarana Sanitasi dan Perilaku Penghuni. Pada kritria tersebut di dalamnya juga terdapat sub kriteria dengan nilai yang sudah ditentukan, kemudian data input berupa nilai untuk masing-masing rumah masyarkat yang didapatkan dari pihak PUSKESMAS.

Dalam menganalisa data akan digunakan metode MFEP, algoritma dalam proses perhitungan dengan menggunakan metode MFEP:

1. Tahapan Menentukan Faktor Dan Bobot Faktor

2. Tahapan Input Nilai Untuk Setiap Faktor

3. Tahapan Perhitungan Bobot Antara Factor Weight Dan Factor Evaluation

4. Tahapan Hasil Perhitungan Metode MFEP

5. Hasil Perangkingan

6. Tahapan Keputusan Sanitasi Rumah Sehat

Langkah-langkah dari metode MFEP untuk mendapatkan hasil keputusan dilihat pada algoritma dan flowchart seperti Gambar 2. Di mana setiap bagian diuraikan setelah Gambar 2.

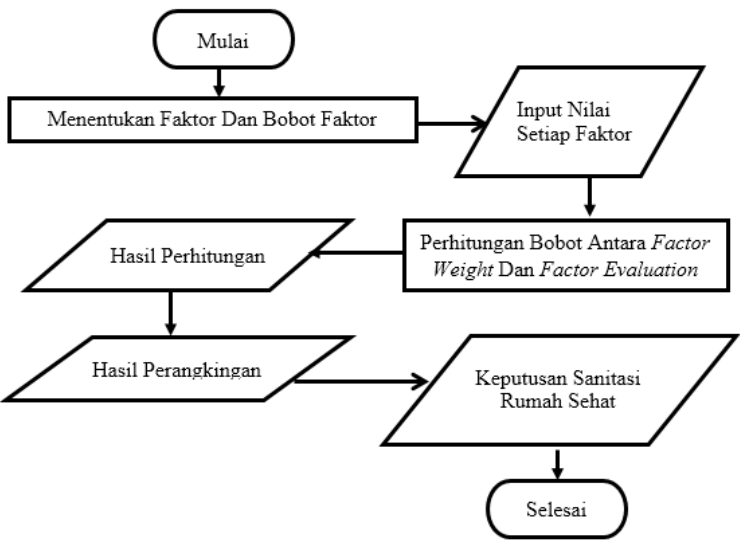

Gambar 2. Flowchart Proses Metode MFEP

1. Menetukan Faktor Dan Bobot Faktor 
Faktor di sini maksudnya adalah kriteria-kriteria yang digunakan dalam SPK ini, di mana setiap faktor akan diberikan bobotnya masing-masing, bobot tersebut didapatkan dari pihak PUSKESMAS Seberang Padang. Berikut adalah faktor dan bobot faktor yang digunakan dalam penelitian ini:

a. Komponen rumah $=\mathrm{K} 1$, Bobot $=31$

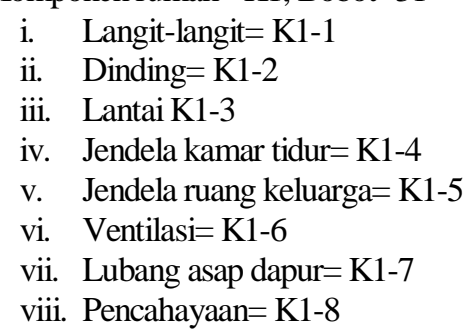

b. Sarana Sanitasi= K2, Bobot $=25$

i. $\quad$ Sarana air bersih= K2-1

ii. Jamban (pembuangan kotoran) $=\mathrm{K} 2-2$

iii. Sarana pembuangan air limbah= K2 -3

iv. Sarana pembuangan $\mathrm{sampah}=\mathrm{K} 2-4$

c. Perilaku Penghuni= K3, Bobot $=44$

i. $\quad$ Membuka jendela kamar= K3-1

ii. Membuka jendela ruang keluarga $=\mathrm{K} 3-2$

iii. Membersihkan rumah dan halaman $=\mathrm{K} 3-3$

iv. Membuang tinja bayi ke jamban= K3-4

V. Membuang sampah pada tempatnya $=\mathrm{K} 3-5$

\section{Input Nilai Setiap Faktor}

Nilai yang digunaka untuk setiap faktor adalah nilai dari rumah masyarakat yang ada di wilayah puskemas. Sebagai contoh akan diambil nilai pada data pertama seperti pada Tabel 1 .

Tabel 1. Data Nilai Rumah

\begin{tabular}{|c|c|c|c|c|c|c|}
\hline \multirow{2}{*}{$\begin{array}{c}\text { Nama } \\
\text { KK } \\
\text { Yuliani }\end{array}$} & \multicolumn{2}{|c|}{$\begin{array}{c}\text { K1 } \\
\text { Bobot } 31\end{array}$} & \multicolumn{2}{|c|}{$\begin{array}{c}\text { K2 } \\
\text { Bobot } 25\end{array}$} & \multicolumn{2}{|c|}{$\begin{array}{c}\text { K3 } \\
\text { Bobot } 44\end{array}$} \\
\hline & K1-1 & 2 & K2-1 & 3 & K3-1 & 2 \\
\hline & K1-2 & 2 & K2-2 & 3 & K3-2 & 2 \\
\hline & K1-3 & 1 & K2-3 & 3 & K3-3 & 1 \\
\hline & K1-4 & 1 & $\mathrm{~K} 2-4$ & 3 & K3-4 & 1 \\
\hline & K1-5 & 1 & & & K3-5 & 2 \\
\hline & K1-6 & 2 & & & & \\
\hline & K1-7 & 2 & & & & \\
\hline & K1-8 & 2 & & & & \\
\hline
\end{tabular}

3. Perhitungan Bobot Antara Factor Weight Dan Factor Evaluation

Untuk melakukan pencarian perhitungan bobot antara factor Weight dan Factor Evaluation dapat dilihat dari Tabel 2.

Tabel 2 Evaluasi Faktor Nilai Kriteria

\begin{tabular}{ccccc}
\hline NO & Factor & Intensitas & Perbandingan & EF \\
\hline 1 & $\begin{array}{l}\text { Komponen } \\
\text { Rumah }\end{array}$ & 31 & $31 / 100$ & 0,31 \\
2 & $\begin{array}{l}\text { Sarana } \\
\text { Sanitasi }\end{array}$ & 25 & $25 / 100$ & 0,25 \\
& & &
\end{tabular}

\begin{tabular}{ccccc}
3 & $\begin{array}{l}\text { Perilaku } \\
\text { Penghuni }\end{array}$ & 44 & $44 / 100$ & 0,44 \\
$\sum$ & 100 & Total & 1 \\
\hline
\end{tabular}

Setelah didapatkan nilai evaluasi faktor setiap kriteria, maka akan dicari nilai evaluasi faktor untuk setiap sub kriteria seperti Tabel 3. evaluasi.

Selanjutnya akan dilakukan proses pencarian bobot

i. Bobot Evaluasi Factor Komponen Rumah:

$W E=0,733 * 0,31=0,227$

ii. Bobot Evaluasi Factor Sarana Sanitasi:

$W E=0,857 * 0,25=0,214$

iii. Bobot Evaluasi Factor Perilaku Penghuni:

$W E=0,6 * 0,44=0,264$

Setelah didapatkan bobot evaluasi selanjutnya akan dilakukan pencarian total bobot evaluasi

$\sum_{i=1}^{n} W E_{i}=0,227+0,214+0,264=0,706$

\section{Hasil Perhitungan Metode MFEP}

Untuk data nilai rumah yang lain juga dilakukan proses perhitungan dengan menggunakan metode MFEP, Hasil perhitungan dan perangkingan untuk setiap data dapat dilihat pada Tabel 4:

Tabel 4. Hasil Perhitungan

\begin{tabular}{cccc}
\hline NO & Nama KK & Hasil & Rangking \\
\hline 1 & Suratman & 0,706 & Rangking 14 \\
2 & Masni & 0,814 & Rangking 5 \\
3 & Dedi Susman & 0,832 & Rangking 4 \\
4 & Hafizah & 0,812 & Rangking 6 \\
5 & Herlina & 0,752 & Rangking 8 \\
6 & Safrijon & 0,752 & Rangking 9 \\
7 & Alex Candra & 0,732 & Rangking 12 \\
8 & Lukman & 0,732 & Rangking 13 \\
9 & Hendra & 0,794 & Rangking 7 \\
10 & Waifaidin & 0,644 & Rangking 16 \\
11 & Pesman & 0,747 & Rangking 11 \\
12 & Ismail Hasan & 0,750 & Rangking 10 \\
13 & Ilham Mutalab & 0,690 & Rangking 15 \\
14 & Firdaus & 0,926 & Rangking 1 \\
15 & Jalius & 0,905 & Rangking 2 \\
16 & Marlius & 0,840 & Rangking 3 \\
17 & Malidi & 0,514 & Rangking 19 \\
18 & Iswardi & 0,474 & Rangking 20 \\
19 & Desmeri & 0,525 & Rangking 18 \\
20 & Fitredi & 0,587 & Rangking 17 \\
\hline
\end{tabular}

Nilai akhir didapatkan dari hasil penjumlahan total bobot evaluasi, sehingga menghasilkan nilai akhir yang nantinya akan dilakukan proses perangkingan dari nilai terbesar ke nilai terkecil.

Pada proses perengkingan didapatkan nilai tertinggi adalah Nama KK Firdaus dengan nilai 0,926, sedangkan nilai terendah adalah Nama KK Iswardi dengan nilai 0,474 . Setelah didapatkan nilai perengkingan, maka akan dilakukan proses pengambilan keputusan berdasarkan nilai batas 
yang sudah ditentukan oleh pihak PUSKESMAS Seberang Padang.

\section{Keputusan Sanitasi Rumah Sehat}

Setelah didapatakan rangking dari masingmasing rumah, maka akan dilakukan pencarian keputusan terhadap hasil nilai tersebut. Nilai batas yang ditapkan dalam menentukan rumah tidak sehat adalah $<80 \%$ dari nilai maksimal, sedangkan $\geq 80 \%$ akan dikategorikan sebagai rumah sehat. Nilai maksimal dari proses perhitungan menggunakan metode MFEP ini adalah 1,00 sehingga $80 \%$ dari nilai maksimal terebut adalah 0,80 , jika hasil akhir nilai dari rumah masyarakat tersebut di bawah 0,80 akan dikategorikan rumah tidak sehat, sedangkan nilai di atas 0,80 akan dikategorikan sebagai rumah sehat. Hasil keputusan di tunukan pada Table 6.

\begin{tabular}{cccc}
\multicolumn{3}{l}{ Tabel 6. Hasil Keputusan } \\
\hline NO & Nama KK & Hasil & Keputusan \\
\hline 1 & Firdaus & 0,93 & Sehat \\
2 & Jalius & 0,91 & Sehat \\
3 & Marlius & 0,84 & Sehat \\
4 & Dedi Susman & 0,83 & Sehat \\
5 & Masni & 0,81 & Sehat \\
6 & Hafizah & 0,81 & Sehat \\
7 & Hendra & 0,79 & Tidak Sehat \\
8 & Herlina & 0,75 & Tidak Sehat \\
9 & Safrijon & 0,75 & Tidak Sehat \\
10 & Ismail Hasan & 0,75 & Tidak Sehat \\
11 & Pesman & 0,75 & Tidak Sehat \\
12 & Alex Candra & 0,73 & Tidak Sehat \\
13 & Lukman & 0,73 & Tidak Sehat \\
14 & Suratman & 0,71 & Tidak Sehat \\
15 & Ilham Mutalab & 0,69 & Tidak Sehat \\
16 & Waifaidin & 0,64 & Tidak Sehat \\
17 & Fitredi & 0,59 & Tidak Sehat \\
18 & Desmeri & 0,53 & Tidak Sehat \\
19 & Malidi & 0,51 & Tidak Sehat \\
20 & Iswardi & 0,47 & Tidak Sehat \\
\hline
\end{tabular}

Dari hasil keputusan di atas sebanyak 30\% rumah dikategorikan sebagai rumah sehat, sedangkan $70 \%$ dikategorikan rumah tidak sehat. Selanjutnya akan dibandingkan keakuratan hasil metode MFEP dengan data yang ada pada pihak PUSKESMAS Seberang Padang seperti berikut:

Selanjtunya akan dibandingkan ke akuratan hasil metode MFEP dengan data yang ada pada pihak PUSKESMAS seperti Tabel 7.

Tabel 7. Perbandingan Keputusan

\begin{tabular}{clcc}
\hline NO & Nama KK & MFEP & PUSKESMAS \\
\hline 1 & Firdaus & Sehat & Sehat \\
2 & Jalius & Sehat & Sehat \\
3 & Marlius & Sehat & Sehat \\
4 & Dedi S. & Sehat & Sehat \\
5 & Masni & Sehat & Sehat \\
6 & Hafizah & Sehat & Sehat \\
7 & Hendra & Tidak Sehat & Sehat \\
8 & Herlina & Tidak Sehat & Tidak Sehat \\
9 & Safrijon & Tidak Sehat & Tidak Sehat \\
10 & Ismail H. & Tidak Sehat & Tidak Sehat
\end{tabular}

\begin{tabular}{llll}
11 & Pesman & Tidak Sehat & Tidak Sehat \\
12 & Alex C. & Tidak Sehat & Tidak Sehat \\
13 & Lukman & Tidak Sehat & Tidak Sehat \\
14 & Suratman & Tidak Sehat & Tidak Sehat \\
15 & Ilham & Tidak Sehat & Tidak Sehat \\
16 & Waifaidin & Tidak Sehat & Tidak Sehat \\
17 & Fitredi & Tidak Sehat & Tidak Sehat \\
18 & Desmeri & Tidak Sehat & Tidak Sehat \\
19 & Malidi & Tidak Sehat & Tidak Sehat \\
20 & Iswardi & Tidak Sehat & Tidak Sehat \\
\hline
\end{tabular}

Dari hasil perbandingan keputusan di atas, terdapat perbedaan hasil keputusan satu data yaitu data pada Hendra, hasil dari metode MFEP menghasilkan Keputusan berupa Rumah Tidak Sehat, sedangkan pada data PUSKESMAS menunjukkan hasil Rumah sehat. Setelah dibandingakan, tingkat perbedaan hasil tersebut adalah sebesar 5\% dan tingkat kesamaan adalah 95\%. Dengan memperoleh tingkat kesamaan $95 \%$ maka metode MFEP dapat digunakan sebagai metode dalam pengambilan keputusan untuk penilaian sanitasi rumah sehat.

\section{Kesimpulan}

Dari hasil keputusan dengan metode MFEP didapatkan sebanyak 30\% rumah teridentifikasi sebagai rumah sehat, sedangkan $70 \%$ teridentifikasi rumah tidak sehat, sedangkan pada data PUSKESMAS 35\% rumah teridentifikasi sebagai rumah sehat, sedangkan $65 \%$ teridentifikasi rumah tidak sehat. Dari hasil perbandingan keputusan di atas, terdapat perbedaan hasil keputusan satu data yaitu data pada Hendra, hasil dari metode MFEP menghasilkan identifikasi berupa rumah tidak sehat, sedangkan pada data PUSKESMAS menunjukan hasil rumah sehat. Setelah dibandingakan, tingkat perbedaan hasil tersebut adalah sebesar 5\% dan memperoleh tingkat kesamaan 95\%. Dengan tingkat kesamaan 95\% maka metode MFEP dapat digunakan sebagai metode dalam identifikasi sanitasi rumah sehat.

\section{Daftar Pustaka}

[1] Mohan, H. T., Masson, L., Kolathayarline, S., Sharma, K. A. K., Krishnan, A. G., Thiviya, S. K., \& Mohan, R. (2017, October). Transforming urban waste into construction blocks for a sanitation infrastructure: A step towards addressing rural open defecation. In Global Humanitarian Technology Conference (GHTC) IEEE. Https://Doi.Org/ 10.1109/GHTC.2017.8239291. (pp. 1-9)

[2] Fiati, R., Murti, A. C. and Chamid, A. A. (2017), "Penentuan Ranking Rumah Sehat Dengan Pendekatan Pemodelan 
PROMETHEE". Sisfo Vol 6 No 2, ISSN: 2355-4614.

[3] Daniati, E. and Nugroho, A. (2016), "K-Means Clustering With Decision Support System Using Saw: Determining Thesis Topic", In Control System, Computing And Engineering (Iccsce), 2016 6th Ieee International Conference On (Pp. 326-331), IEEE, DOI: HTTPS://DOI.ORG/ 10.1109/ICCSCE.2016.7893593.

[4] Vhallah, I., Sumijan, S., \& Santony, J. (2018). Pengelompokan Mahasiswa Potensial Drop Out Menggunakan Metode Clustering KMeans. Jurnal RESTI (Rekayasa Sistem dan Teknologi Informasi), 2(2), 572-577.

[5] Na'am, J. (2017). Sebuah Tinjauan Penggunaan Metode Analytic Hierarchy Process (AHP) dalam Sistem Penunjang Keputusan (SPK) pada Jurnal Berbahasa Indonesia. JURNAL ILMIAH MEDIA SISFO, 11(2), 888-895.

[6] Mohamed, H. H., Arshad, M. R. H. M., \& Azmi, M. D. (2016). M-HAJJ DSS: A mobile decision support system for Hajj pilgrims. In Computer and Information Sciences (ICCOINS), 20163rd International Conference on

IEEE. Https://Doi.Org/10.1109/ICCOINS.2016.7783 202 (pp. 132-136).

[7] Shirsath, R., Khadke, N., More, D., Patil, P., \& Patil, H. (2017, June). Agriculture decision support system using data mining. In Intelligent Computing and Control (I2C2), 2017 International Conference on (pp. 1-5). IEEE. Https://Doi.Org/ Https://Doi.Org/ 10.1109/TITS.2018.2809642.

[8] Abdelghany, K., Hashemi, H., \& Khodayar, M. E. (2018). A Decision Support System for Proactive-Robust Traffic Network Management. IEEE Transactions on Intelligent Transportation Systems. Https://Doi.Org/ 10.1109/TITS.2018.2809642.

[9] Polmetra., Nurcahyon, W. M., \& Defit, S. (2015). Sistem Pendukung Keputusan Dengan Metode Analitical Hierarchy Procces (Ahp) Untuk Pemilihan Pelatih Bulutangkis. Prosiding Seminar Ilmiah Nasional Teknologi Komputer (SENATKOM 2015), 1(1).

[10] Turaina, R., Nency, E.P and Redo, R. (2017). Spk Dalam Pemilihan Siswa Kelas Unggul Menggunakan Metode Mfep Di Smp N 2 Solok. Urnal Edik Informatika (Vol. 3, No. 2, Pp. 125-135).

[11] Adi W., \& Mujito. (2017,). Implementation Of The Algorithm Of Multi-Factor Evaluation Process (MFEP) For The Election Of The Members Of The Investigator At Bareskrim Police, 2017 International Journal of Pure and Applied Mathematics (pp. 381-394).
[12] Maricar, M. A., Wahyudin, W., \& Sudarma, M. (2016). Decision Support System of the Employees Acceptance using Analytical Hierarchy Process (AHP) and Multi Factor Evaluation Process (MFEP). International Journal of Engineering and Emerging Technology, 1(1).

[13] Primadasa, Y. and Amalia, V. (2017). Penerapan Metode Multi Factor Evaluation Process Untuk Pemilihan Tanaman Pangan Di Kabupaten Musi Rawas. Sisfo 7 Vol 7 No 1, 7.

[14] Turaina, R. and Efendy, C. G. (2016). Sistem Penunjang Keputusan Penerimaan Calon Tenaga Honorer Di Sma N 1 Junjung Sirih Kab. Solok Menggunakan Metode Multifaktor Evaluasi Proses (Mfep). Jurnal Momentum, 18(2).Https://Doi.Org/10.21063/Jm.2016.V18. 2.pp.60-66 